\title{
EXPERIENCES OF UIN ALAUDDIN LIBRARY DATA MIGRATION FROM THE OLD SYSTEM TO A NEW ONE
}

\author{
Taufiq Mathar ${ }^{1}$, Andi Marwansyah ${ }^{2}, \&$ Feri Ardinata ${ }^{3}$ \\ ${ }^{1}$ Department of Library Science, Universitas Islam Negeri Alauddin Makassar \\ ${ }^{2,3}$ UIN Alauddin Library, Universitas Islam Negeri Alauddin Makassar \\ Correspondence email: taufiq.m@uin-alauddin.ac.id
}

\begin{abstract}
Currently, many libraries have implemented library automation systems or integrated library system. The conventional services are replaced by technology-based services. This article describes the experience of Alauddin UIN Library in migrating data from the old to a new system. This descriptive study uses a case study approach. The data were obtained from observations and experiences of the library staff involved during the migration processes. The study showed that the system transition was carried out because the old system had experienced several obstacles, migrating data required established planning. In addition, the library must also consider the time, cost, funds, and competent human resources. The hardest obstacle faced by the library during migration was in the data conversion section in which there were differences in data structures between the two systems. This study can be used as a reference for other libraries that planning to migrate to a new library system.
\end{abstract}

Keywords: Data migration; library management system

\begin{abstract}
Abstrak
Saat ini banyak perpustakaan telah menerapkan sistem otomasi perpustakaan. Pelayanan konvensional digantikan dengan pelayanan berbasis teknologi. Artikel ini menggambarkan pengalaman Perpustakaan UIN Alauddin memigrasikan datanya dari sistem lama ke sistem yang baru. Penelitian deskriptif ini menggunakaan pendekatan studi kasus. Data diperolah dari hasil pengamatan dan pengalaman staf yang terlibat dalam proses migrasi data. Penelitian ini menunjukkan bahwa peralihan sistem yang dilakukan perpustakaan karena sistem lama telah mengalami beberapa kendala, migrasi data memerlukan perencanaan yang mapan. Penting untuk ditekankan, perpustakaan juga harus mempertimbangan waktu, biaya, dana, dan juga sumber daya manusia yang kompeten Ketika hendak beralih ke sistem baru. Kendala terberat yang dihadapi perpustakaan ketika migrasi ada pada bagian konversi data di mana terdapat perbedaan struktur data antar kedua sistem. Kajian ini dapat dijadikan sebagai salah satu rujukan bagi perpustakaan-perpustakaan yang hendak melakukan migrasi data.
\end{abstract}

Kata kunci: Migrasi data; sistem automasi perpustakaan 


\section{Introduction}

For more than a half century ago, computer technology had played a significant role in helping daily routines. Until now, in almost every sector of life, technology is used and works according to its function. Due to this significant role, many libraries also implement similar technology devices. Computerization within the library has been appeared since a few decades ago till now and continues to grow. There is what is called a library automation system or integrated library system (ILS). This system has greatly helped library management in increasing efficiency of library operations, access to library collections, and connecting other information sources (Chow and Bucknall, 2012a).

Library automation systems have been used in various types of libraries. Ranging from simple to complex automation systems. In the context of academic libraries, which certainly require a solid system, the library automation requires should provide fast and accurate services for its patrons. Therefore, academic libraries should aware in choosing and determining a library management system. Some academic libraries eternally decided to switch for a new system because constraints faced the previous system.

Some cases of data migration from one system to another are studied. Chattopadhyay and Sarkar (2017) described the stages of data migration from LibSys to KOHA. One of the findings was that checking data consistency is an important thing to do in the data migration process. A similar study was written by Oinam dan Nongbri (2016). A workshop report published by the Central Library of the National Institute of Technology Rourkela BIJU, in the first part of the report, it illustrates how data migration at $\mathrm{KOHA}$ is carried out. The results of the presentation on KOHA data migration were also described by Hughes (2013). Meanwhile, related to the technical matters during data migration experienced by librarians was mentioned by Singh (2017). Other data migration cases are written by Oghenevwogaga Adogbeji et al. (2013), and Chiparausha, Musarurwa, and Chigwada (2016). The latter stated that because of the limitations of the old system, the library adopted the latest technology in order to accommodate the demands of library users.

Data migration is the process of moving data from one data storage medium to another. According to Thalheim and Wang (2013), data migration is the process of moving data from legacy data sources of a legacy system into new data sources of a target system, in which legacy and new systems have different data structures. Data migration from one system to another has at least been experienced by any organization. Some factors are the old system no longer fits with the current circumstances, the equipment is outdated, the rapid development of technology, and maintenance costs (Matoria and Upadhyay, 2005). The same thing has been occurred in academic libraries.

Migrating data from one system to another is not an easy task and failures might occur. Data loss and data damage become important things to notice when a library is about to migrate for a new system (Matoria and Upadhyay, 2005). 
However, the data migration presents its own challenges and valuable experiences for libraries that wanted to use a new platform. As experienced by Universitas Islam Negeri Alauddin Library (UIN Alauddin Library) in the early 2016. This study will describe the stages of data migration that the library was moving its whole data from the previous system called Electronic Library Management Ssytem (ELiMS) to Senayan Library Management System (SLiMS) without comparing both systems in detail.

\section{Methods}

This descriptive study uses a case study approach. The data were obtained from interviews with the library staff and direct observations during the library was moving its whole data to the new system. The data was analyzed and specifically described in accordance with the data migration stages which are divided into three main stages; before, ongoing, and until after the data migration process was accomplished in the early 2016. This paper will not describe in detail the reasons why the library has switched to a new system. Likewise, technical matters during the migration process were not described in more specific, but in general view.

\section{Results}

One challenge is often faced by many libraries is when their library management system faced problems or damages or is not up-to-date. Meanwhile, to repair or renew it certainly requires additional costs. The problem will be more getting difficult to solve if the system providers are quite hard to contact. This might effect library performances, because as mentioned by Chow and Bucknall (2012b) that the majority of library routines are in the automation system used, especially in academic library. Therefore, it is worthy to note that in determining a library automation system, a robust planning is needed, either in the short or long term.

UIN Alauddin Library had implemented a library automation system since 2009. At that time, Electronic Library Management System (ELiMS) was used. Till the end of its use, in the beginning of 2016, there were more than 20,000 bibliographic data within the system consisted of library items such as books, magazines, journals, proceedings, research reports, and other collections. Loan transactions and membership were also existed with the total of more than ten thousand of records. The system is supported by sophisticated hardware such as self-service machines, RFID tagging machines, and book-drop (fast service to return library items).

Over the time, in 2014 it began to experience obstacles. Eternally, in the end of 2015, the system was replaced by a new system, called Senayan Library Management System (SLiMS). Data migration was then carried out and took few days to complete from the end of February till the beginning of March 2016. From the interviews with the data migration library team, and direct observations during migration, the process of data migration in general is described in the next page. 


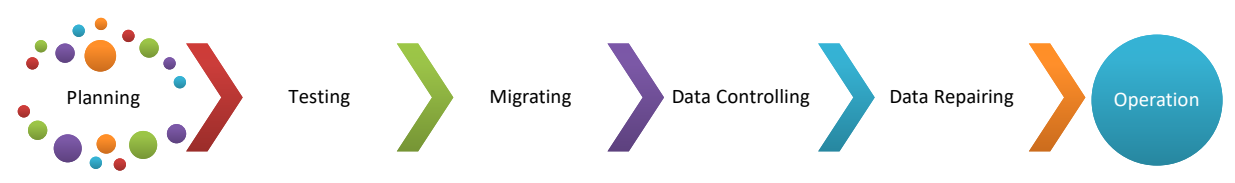

Figure 1. Data migration stages of UIN Alauddin Library in 2016

\section{a. Planning}

No one can deny that planning is important. All impacts that will occur must be studied and carefully considered at the planning stage. In this case, the library has amounts of more than 20,000 bibliographic records, more than ten thousand of library members, transaction statistics, and so forth. At this stage, the quality of the data is fully noticed to ensure that the existing data in the previous system can be transferred completely and accurately without failures.

In fact, there are differences in data table structures between the previous system and the new one. So, at this planning stage, the team carefully studied the two tables were displayed in Ms. Excel format (*.xls). Once the structures were clearly understood, the previous data was then converted in following the new system. Furthermore, more than twenty thousand of bibliographic records from the previous system were divided into several parts. It was just to ensure that the migration went smoothly. Each part of bibliographic records was formatted into a single Comma Delimited (*.csv) file that contained around hundreds of lists. This data conversion produced about dozens of *.csv files followed SLiMS's table structures and were ready to transfer (import) into the new system. This planning stage, especially the data conversion section took a few days for nine data migration team members.

\section{b. Testing/Simulation}

Before the data was transferred to the new system, a simulation or testing was performed on a single computer that has already installed the new system software, SLiMS. This testing process is very important to prevent damages or data loss. During the simulation, the team encountered few challenges. Among them, like unreadable item barcodes, some fields in bibliography do not fit into place in the new system, and membership status was not active. For the latter mentioned directly overcome by reactivating the status when a library user will borrow library collections. It was interesting to highlight that during simulation the team found poor data in the previous system and it was then corrected immediately. As mentioned earlier that data migration can improve the quality of the data itself.

\section{c. Migrating}

Before moving the whole data, a new database was set into the library server along with its new library software, SLiMS. Once it was ready to use, the whole data was then transferred into that new database. The simulation stage above has much influenced this stage. 


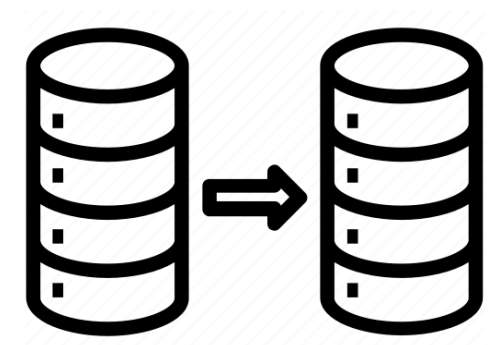

Figure 2. Illustration ELiMS database to SLiMS database

\section{d. Data Controlling}

In this stage, the whole migrated data was always controlled for accuracy. Each team member has a responsible duty. The control is carried out directly through the new system. For example, a member will check the accuracy of bibliography for each book transferred to the new system throughout the library OPAC, and to make sure that book can be borrowed. If there was data failed, the team will recheck into the system and overcome the problems.

\section{e. Data Repairing}

The most time-consuming stage was at the data repair. At this stage, most data found inaccurate or poor once appeared in the new system. The team found inaccurate data, especially in the barcode section. For example, books barcodes cannot be read. It was due many barcodes in the previous system using dashes ( - ) between two groups of numbers as book barcodes. In fact, the new system was unable to read the dash. Therefore, the team eliminated the numbers after the dash in the new system as a solution and new barcode assigned for every library collection that have those dashes. It took time, but it must do.

\section{f. Operation}

After the whole data were confirmed to migrate and ready to use, at this stage the library system began to operate by librarians, staff and library users. For the librarian and staff, the team have trained and introduced features of the new system along with their functions. For the library users, the library has interestingly set a new library OPAC (figure 3) because it is the most often used by users. The figure below shows the new Alauddin Library's OPAC appeared on March 2016. Since it was first operated in 2016 until now, the system runs smoothly, even though it still remains some challenges.

\section{Discussions and Conclusion}

Migrating data from one system to another considers several things, including technical matters. One important thing is the quality of the data itself. Data migration might improve the quality of the data. Where the new system found damaged or problematic data from the previous system, that data can be corrected immediately. In addition, competent staff must also be involved in the data 
migration process. Their experiences will succeed the process. Above all, a robust planning to have a library management system is a crucial step before other steps through. UIN Alauddin Library, with its limitations succeeded to switch and move their whole data to the new system. These experiences have given valuable insight for future developments.

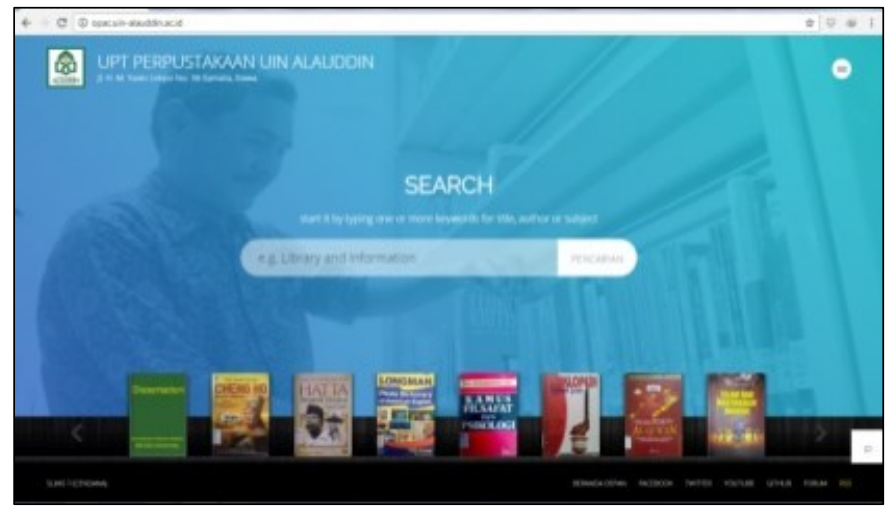

Figure 3. New UIN Alauddin Library's OPAC

\section{Acknowledgement}

We thank to the Head of UIN Alauddin Library in the periods 2009-2015, 20152019. We also thank to the librarians and staff (data migration team) involved in who sincerely gave us sophisticated data for this study.

\section{References}

BIJU Central Library National Institute of Technology Rourkela. (n.d.). Step By Step Guide To Implement Quality Improvement.

to Koha: Experience at St. Xavier's College, Kolkata. Indkoha 2017, 159-167.

Chiparausha, B., Musarurwa, B., \& Chigwada, J. (2016). Experiences with library management system migration at Bindura University of Science Education (BUSE), (Phadke 2015), 117-123.

Chow, A. S., \& Bucknall, T. (2012a). Customized fashion: finding the right fit. Library Technology and User Services, 33-79. https://doi.org/10.1016/b978-184334-638-8.50003-5

Chow, A. S., \& Bucknall, T. (2012b). Emerging technology trends in libraries. Library Technology and User Services, 105-130. https://doi.org/10.1016/b978-184334-638-8.50006-0

Hughes, D. (2013). Migration to the Koba Open Source LMS: the DBS Library Experience.

Matoria, R. K., \& Upadhyay, P. K. (2005). Migration of data from one library management system to another: A case study in India. Program, 39(2), 160166. https://doi.org/10.1108/00330330510595733

Oghenevwogaga Adogbeji, B., N Nwalo, K. I., Vera, N., Oghenevwogaga Toyo, 
D., Adogbeji, B. O., Nwalo, K. I. N., ... Toyo, D. O. (2013). Software Migration in Selected University and Special Libraries in Nigeria. International Joumal of Academic Research in Business and Social Sciences, 3(4), 33-43. Retrieved from www.hrmars.com/journals

Oinam, A. C., \& Nongbri, J. P. (2016). Software Migration from LibSys 4 . 0 to Koha : Post Migration Scenario in a University Library of North-Eastern Hill University, Shillong, Meghalaya , India, 9-11.

Singh, V. (2017). Open source integrated library systems migration: Librarians share the lessons learnt. Journal of Librarianship and Information Science, 096100061770905. https://doi.org/10.1177/0961000617709059

Thalheim, B., \& Wang, Q. (2013). Data migration: A theoretical perspective. Data and Knowledge Engineering, 87, 260-278.

https://doi.org/10.1016/j.datak.2012.12.003 